\title{
Modern Italy
}

Date of delivery:

Journal and vol/article ref:

$$
\text { mit } 1700054
$$

Number of pages (not including this page): ${ }^{16}$

This proof is sent to you on behalf of Cambridge University Press. Please print out the file and check the proofs carefully. Please ensure you answer all queries.

\begin{tabular}{l|ll} 
Please EMAIL your corrections within & 3 days of receipt to:
\end{tabular}

\section{Jeenath Chowdhury: mitproduction@cambridge.org}

Please also download a copyright form

https://www.cambridge.org/core/journals/modern-italy/information/transfer-copyright complete, sign, and return it to cmoffet@cambridge.org

Authors are strongly advised to read these proofs thoroughly because any errors missed may appear in the final published paper. This will be your ONLY chance to correct your proof. Once published, either online or in print, no further changes can be made.

NOTE: If you have no corrections to make, please also email to authorise publication.

- The proof is sent to you for correction of typographical errors only. Revision of the substance of the text is not permitted, unless discussed with the editor of the journal. Only one set of corrections are permitted.

- Please answer carefully any author queries.

- Corrections which do NOT follow journal style will not be accepted.

- A new copy of a figure must be provided if correction of anything other than a typographical error introduced by the typesetter is required.

- If you have problems with the file please email mitproduction@cambridge.org Please note that this pdf is for proof checking purposes only. It should not be distributed to third parties and may not represent the final published version.

Important: you must return any forms included with your proof. We cannot publish your article if you have not returned your signed copyright form

\section{Please do not reply to this email}

NOTE - for further information about Journals Production please consult our FAQs at http://journals.cambridge.org/production_faqs 


\section{QUERY FORM}

\begin{tabular}{|l|c|}
\hline \multicolumn{2}{|c|}{ MIT } \\
\hline Manuscript ID & [Art. Id: 1700054] \\
\hline Author & \\
\hline Editor & \\
\hline Publisher & \\
\hline
\end{tabular}

\section{Journal: Modern Italy}

Author :- The following queries have arisen during the editing of your manuscript. Please answer queries by making the requisite corrections at the appropriate positions in the text.

\begin{tabular}{|c|c|}
\hline Query No & Nature of Query \\
\hline Q1 & $\begin{array}{l}\text { The distinction between surnames can be ambiguous, therefore to ensure accurate tagging for indexing purposes } \\
\text { online (e.g. for PubMed entries), please check that the highlighted surnames have been correctly identified, that all } \\
\text { names are in the correct order and spelt correctly. }\end{array}$ \\
\hline Q2 & Please check and provide the Reference for the text citation "Antonio Gallenga (1810-1895)" in the Reference list. \\
\hline Q3 & Please check and provide the Reference for the text citation "Quintino Sella (1827-1884)" in the Reference list. \\
\hline Q4 & $\begin{array}{l}\text { Please check and provide the Reference for the text citation "Abbott Lawrence Lowell (1856-1943)" in the } \\
\text { Reference list. }\end{array}$ \\
\hline Q5 & $\begin{array}{l}\text { Please check and provide the Reference for the text citation "William Livingstone Alden (1837-1908)" in the } \\
\text { Reference list. }\end{array}$ \\
\hline Q6 & Please check and provide the text citation for ref. "Ambrosini 2016”. \\
\hline Q7 & Please check and provide the text citation for ref. "Duggan 2000". \\
\hline Q8 & Please check and provide the text citation for ref. "Ehrenkranz et al., 1988". \\
\hline Q9 & Please check and provide the text citation for ref. "Ferrero 1895 ". \\
\hline Q10 & Please check and provide the text citation for ref. "Sutherland 1989". \\
\hline
\end{tabular}




\title{
William Stillman: championing Crispi in late Victorian Britain
}

\author{
Bavid Laven*
}

Department of History, University of Nottingham, UK

(Received 11 July 2017; Revised 23 August 2017; final version accepted 23 August 2017)

Christopher Duggan made extensive use of the correspondence of the American Times journalist William James Stillman in writing his important biography of Francesco Crispi. This article focuses on Stillman's published works that deal with the Italian statesman, principally his 1898 history of Italy since 1815, the first and only Englishlanguage biography of Crispi until Duggan's, and the journalist's own autobiography. It argues that, despite Stillman's much vaunted love for Italy, he in fact despised most Italians, and saw in Crispi's virtues a rejection of typical Italian conduct. While Stillman was extreme but not altogether unusual among British and American commentators on Italy in his passionate support for Crispi, his contempt for Italians was surprisingly widespread among late Victorian observers of the new nation.

Keywords: Francesco Crispi; William Stillman; Christopher Duggan; The Times; Adowa; Ouida; William Alden; Giuseppe Fiamingo

\section{Crispi's anglophone biographers}

Christopher Duggan's Francesco Crispi, 1818-1901: From Nation to Nationalism was published by Oxford University Press in 2002. The Italian version - Creare la nazione. La vita di Francesco Crispi - had appeared two years earlier. In the introduction to this exhaustive and brilliant political biography, Christopher emphasised the degree to which Francesco Crispi had been neglected in the historiography, remarking that 'even in Italy there has been no thorough full-length study of his life in the hundred years that have elapsed since his death' (Duggan 2002, 1). But Christopher's biography was not the first English-language life of the Mazzinian, garibaldino, and two-time prime minister, who - with the possible exception of Giovanni Giolitti - was the most significant political figure of Italy's liberal era. As Christopher made clear, his study had precedent in William James Stillman's Francesco Crispi. Insurgent, Exile, Revolutionist, and Statesman, published in 1899, just over a century earlier, shortly before the deaths of both author and subject in the summer of 1901 .

Born in Schenectady, New York, in 1828, Stillman spent most of his adult life in Europe, between England, Switzerland, Greece, and Italy (Dyson 2014; Stillman 1901). Among historians of Italy he is best known as the Rome correspondent of The Times, but he was blessed with a wide range of talents. He was the author of many books, of which the best known was his study of the Cretan rising against Ottoman rule (Stillman 1874); as a journalist and essayist, he wrote widely for many periodicals besides The Times; he was a pioneering photographer especially of ancient sites, ${ }^{1}$ and an amateur archaeologist and sometime diplomat (Georgi, 2013). ${ }^{2}$ He was additionally a not especially distinguished member of the Hudson River School, who became friendly in

\footnotetext{
*Email: david.laven@nottingham.ac.uk
} 
England with the leading Pre-Raphaelites, knew Turner in the great artist's old age, and was an acquaintance of that painter's great advocate, Ruskin; among other famous men, Stillman was friendly with Browning, Kossuth, and Gladstone. It was, however, while working for the Times in Rome that Stillman came to know Crispi well - probably better than any other foreign journalist - and henceforth often wrote about him in his articles and in his private and business correspondence, notably in letters to the famous Russianist and fellow-Times foreign correspondent, Donald Mackenzie Wallace (1841-1919) (Dyson, 2014; Morren, 1967). Christopher made extensive use of Stillman's letters to Wallace to cast light on Crispi's personality and career in the 1880s and 1890s. As Christopher remarked, Stillman was 'intelligent and highly regarded', and it is clear that in writing his exhaustive study of Crispi, Christopher judged the polymath journalist to be an astute and valuable observer of both Italian affairs and of the Sicilian statesman in particular. But Christopher did not make significant use of Stillman's biography of Crispi, of The Times, or of the several other published works in which the journalist dealt with him beyond the pages of England's most famous newspaper. It is on these writings that this article will focus, to see what they tell us about anglophone attitudes to Crispi and more generally about Italy in the final years of the nineteenth century.

Besides his 1899 biography of the Italian prime minister, Stillman wrote two books in which Crispi featured heavily: The Union of Italy, 1815-1895, published in 1898, and The Autobiography of a Journalist of 1901; the last fifty pages of the latter are incredibly rich in their treatment of Crispi, including some sections dedicated solely to the Italian prime minister. Although Stillman had come to know many powerful and influential individuals in the course of his varied and exciting life, Crispi was perhaps the single person to whom he attached the greatest significance. Indeed, Stillman's intense admiration for Crispi appears to have stemmed both from the journalist's disillusionment with Italy, and from his being seduced by his unusual degree of access to a statesman, who understood the power of the press but who was often suspicious of journalists. In addition to the three books in which Crispi played a significant, even dominant, rôle, in 1894 Stillman also published a substantial article simply entitled 'Francesco Crispi' in the influential Century Magazine - the highly successful New York journal and more popular successor to Scribner's Monthly (Stillman, 1894), edited by the poet Richard Watson Gilder (Smith, 1970; John, 1981). In this piece Stillman summarised most of what he had implied in his journalism for The Times and would articulate in his later and fuller writings on the statesman. There is not space here to deal with Stillman's writing for The Times in any detail, but it is important to note the degree that his contributions were invariably parti pris in their support for Crispi. Thus, for example, when Crispi was effectively forced into resignation early in 1891, Stillman confidently (and wrongly) predicted that he would be back at the helm of a new ministry within a matter of months, notwithstanding the vicious and ill-justified hostility of the Italian press, which, according to the American, unjustly persecuted and falsely attacked the most outstanding individual in Italian politics.

My conviction is that vote of Saturday, so far from being the end of Crispi $[\ldots]$ is the decree of ostracism of the men responsible for it, so far as Italian politics have any continuity, and that it has really made Crispi's position stronger. The man whose motto is frangar non flectar will always be worshipped by Italians. (Stillman 6 February 1891)

When a new ministry was formed, not under Crispi but under another Sicilian, Antonio Starabba Marchese di Rudinì, Stillman's response was to ridicule its divisions, taking the opportunity to compare Crispi favourably with the fractious mediocrities who made up his political rivals. 
[...] the new Ministry reveals the confirmation, in its composition, of the incoherent nature of the attack on Signor Crispi, and shows the want of conformity in the views and politics of the new Ministers. In fact, it is impossible to conceive a more complete conglomeration of antagonisms than it contains. (Stillman, 16 Feb. 1891)

Highly partisan support for Crispi characterised pretty much everything that Stillman wrote about Italy in the pages of The Times after he became its permanent Rome correspondent in 1886, following the death of the p resident Times journalist and the effective retirement of Antonio Gallenga (1810-189 She Times's special Italian correspondent (Dyson 2014, 247). That no one within the hierarchy of The Times sought to moderate Stillman's wholehearted, even aggressive, backing for Crispi is noteworthy given the degree to which the editors sought to position it as an impartial and authoritative journal of record. Nevertheless, neither George Earle Buckle, the editor from 1884, nor Charles Frederic Moberly Bell, who from 1890 was its managing director, seem ever to have tried to curb Stillman's enthusiastic endorsement of Crispi. Instead, Stillman continued the favourable relations he had enjoyed, when he was still just a casual reporter, with their predecessors, Thomas Chenery and John Cameron MacDonald, (Dyson 2014, 248; Stillman 1901, 663, 688): he wrote with complete freedom.

Stillman's fierce loyalty to and admiration for Crispi also featured in other shorter pieces not written for The Times. Sometimes he could not help himself from including laudatory allusions to Crispi, even when the subject matter scarcely called for them. One example of this is to be found in his collection of essays, The Old Rome and the New, a volume drawn from articles previously published in a variety of literary journals. The eponymous opening essay consists principally of Stillman's musings on the Hellenic influences on the ancient city, on the beauty of the surrounding countryside, on the enduring nature of Rome's 'charm', and of the author's inveighing against the horrible and tawdry transformation of the city since it had become the capital of united Italy: 'The transformation of Rome during the past twenty years is unique in the history of civilisation for barbarism, extravagance, and corruption: never since the world began was so much money spent to do so much evil' (Stillman, 1897, 15). Such statements hint at Stillman's scant respect for the post-unification political status quo. Yet he singled out just one coeval politician by name, and mentioned him only in positive terms: the reader learned that deaths from malaria around Rome had declined as a direct result of the 'amelioration in the condition of public health' effected 'under the government of Crispi' (Stillman, 1897, 21). These remarks encapsulate Stillman's position on liberal Italy as it was expressed in his other writings: he argued from his own rich, first-hand experience to establish his position of authority and privilege with regard to the reader, before juxtaposing his distaste for the state of Italy, against his praise for the great Crispi.

\section{Crispi's creature?}

As both his biography of Crispi and his autobiography underline, Stillman came to know Crispi well during the latter's first ministry. Yet Stillman always stressed in his writings that he was not in any sense Crispi's creature, that he had neither come under the politician's influence nor been seduced by his charisma; that Crispi had neither favoured him nor sought to influence his writing; that a distance was always maintained. In his autobiography, Stillman remarked:

Crispi and I were never intimate, and the supposed confidence between us never extended beyond the communication of political matter which he thought should be made public, and which could be made public without violation of official secrecy. He had far too high an estimate of his position as the head of the government of one of the powers of Europe to enter into intimacy with a correspondent of even the 'Times', a journal of which, nevertheless, he always spoke with the respect due another power. 
Did Stillman protest too much? Given that many contemporaries clearly did believe that Stillman had become little more than Crispi's unofficial mouthpiece, ${ }^{3}$ it is worth reflecting in greater detail on Stillman's own narrative of his relationship with Italy's most well-known politician. At the very beginning of Francesco Crispi, Stillman describes how his first meeting with the prime minister had not gone well. On the instructions of his editor, Stillman had sought an audience with Crispi in the Palazzo della Consulta shortly after the formation of his first ministry in the summer of 1887, with the intention 'to learn the Mediterranean policy of the new ministry in order that we [The Times] might support it.' Crispi had greeted the Times correspondent first with silence and 'the expression of a suspicious watch-dog', and then with the curt response " The Government has no need of the support (appoggio) of the Press"' (Stillman 1899, 2). Within a few weeks Crispi realised that 'his independence from the press was not as absolute as he supposed'; he soon made himself more accessible and did all 'that his always brusque manner permitted to remove the impression of our former interview' (Stillman 1899, 2). According to Stillman's published accounts the relationship between the two men changed again later in the ministry. This transformation occurred during the course of negotiations between the British and Italians over Kassala, which opened in Naples in September 1890 and led, in April 1894, to a protocol that would result in the Italian occupation of the Sudanese city (Gooch 1998, 135-136). Stillman explained that, as the sometimes difficult negotiations progressed, Crispi altered his opinion of him, although here too - as in his autobiography - he dismissed the notion that they were close:

It was in the course of these negotiations that Crispi became convinced that I was a real friend of Italy, and from that time forward he was accustomed to communicate to me confidentially such matters as were of public interest for publication; but there was, neither then nor later, the intimacy between us which English and French journals supposed, and on the strength of which supposition all my views of Italian politics were believed to be the reflection of those of Crispi. The fact was, that there was never any other intimacy between us than that of an honest minister towards an honest journalist, for Crispi is not a man to make an intimate amongst journalists, for whom in general he had a strong aversion [...] (Stillman 1899, 2-3).

Stillman underlined this story in his autobiography, explaining how Crispi ceased to treat him as he did most journalists, merely with 'a distant civility', and came to recognise someone who genuinely cared for the peninsula's domestic welfare and stability, as well as for Italy's international status (Stillman 1901, 698). At the same time the journalist was determined to quash the widespread opinion that Crispi did him special favours and that he was a privileged advocate. Despite his energetic attempts to affirm that he and Crispi maintained an appropriately professional distance, the sense that Stillman was essentially a propagandist for the Italian statesman remained widespread.

The far from indulgent reviews given to Stillman's work in British and American periodicals suggest that his contemporaries generally thought that he was too close to Crispi, too much under the politician's influence, and unable to make a fair assessment of Italy and its inhabitants because he saw matters invariably from Crispi's perspective. Stillman was sufficiently respected as a journalist and widely-esteemed as a writer for colleagues on both sides of the Atlantic to see merits in his work, but even the most positive reviews tended to come with a note of caution. One piece, dating from July 1899 and published in the middlebrow literary journal The Bookman, identified some laudable aspects in the approach of the Times journalist (The Bookman, 1899). Nevertheless, it also condemned him for overstating his case and for vilifying just about every other leading political figure including Cavour, 'whom he pursues with relentless animosity', and Mazzini. Above all the reviewer criticised Stillman, the 'old and devoted lover of Italy', for his total pessimism about the country and its inhabitants, 'too poverty-stricken in strength and ideas'. 
Stillman, the conclusion of the article implied, seemed unaware of or wilfully ignored 'faint signs that sleepers in Italy are stirring with nobler dreams than Crispi's' (The Bookman, 1899). Significantly less indulgent to the author - and to Italians - was a review in The Academy, published the following month.

The piece in The Academy began by stressing that the book was overwhelmingly biased in favour of Crispi: 'Mr. Stillman's biography is partisan. Apologia pro Vita Crispi it might have been called, without the least exaggeration of its contents.' The review then continued by attacking Crispi for being 'a vulgared [sic] Bismarck', as unscrupulous as the Prussian, but additionally tarnished by a 'revolutionist' past: Crispi was an instigator of terror and assassination who hypocritically 'rallied to the support of the new Italian monarchy and constitutional opposition' (The Academy, 1899, 154-155). Meanwhile, The Athenceum review of Francesco Crispi deemed Stillman 'somewhat too friendly to its hero to be entirely trustworthy', for while Crispi was undoubtedly possessed of 'talent, vigour, and resource', he was also given to 'Rhadamanthine severity': 'deserved as may be the panegyric on his [Crispi's] ability, the book before us is to his demerits somewhat blind' (The Athenæum, 1899).

Although some reviewers noted Stillman's exceptional qualification to write about the Italian statesman - The Observer's comment was that Stillman had 'probably the best claim to write of Crispi' and that his 'critical disposition and personal sympathies were fairly balanced' (The Observer, 9 July 1899, 7) -, the general trend was to question Stillman's impartiality and judgement, while taking the opportunity offered by a review to attack an authoritarian, vain, and headstrong politician. Richard Davey was typical: reviewing The Autobiography of a Journalist for The Speaker, he saw Stillman as guilty of having 'converted the great organ he served into a somewhat too pronounced reflection of the views of one who had undoubted talent and force of character, but whose influence on Italian policy was rather baneful than otherwise': 'Verily Mr. Stillman's idol had feet of clay. ${ }^{4}$ Despite courting critical reviews, Stillman's position on Crispi remained remarkably consistent: there is little sign in his writing that he ever questioned for a moment the great worth and abilities that he identified in the statesman.

It is important in assessing Stillman's views of Crispi to recognise that until 1860 the future prime minister was almost entirely unknown in Britain. In the pages of The Times, for example, his name appears just twice before the dramatic events of 1860: once in 1848 in a brief allusion to his role in unrest in Sicily (The Times, 7 February 1848), and again in 1855 when he was expelled from Malta and boarded a ship for Portsmouth (The Times, 8 January 1855). ${ }^{5}$ In 1860 Crispi suddenly sprang to prominence on account of his place alongside Garibaldi in the conquest, administration, and eventual annexation of the Kingdom of the Two Sicilies. During 1860, The Times tended to portray Crispi as a dangerous and disruptive force, his name linked closely with that of the radical physician Agostino Bertani, who in 1866 worked with Crispi to found the latter's political mouthpiece, La Riforma (Duggan 2002, 292-295). For example, in an article in late September the paper stressed Crispi as a bad influence on Garibaldi (The Times, 25 September 1860); another a week later warned of 'an immense amount of mischief' Bertani and Crispi might cause even without the declaration of a republic (The Times, 2 October 1860). The Times was by no means alone among British and Irish newspapers in viewing Crispi negatively during the course of the annus mirabilis of Italian unification. ${ }^{6}$ Much of the press deemed Crispi's Mazzinian republicanism the biggest threat to the smooth transition of the peninsula to constitutional rule under the House of Savoy. In January 1861, The Times suggested that it was more or less impossible to cooperate 'with Bertani, Crispi, or the other leaders of the Mazzinian faction' on account of 'their grievous errors and extreme subversive political views' (The Times, 19 January 1861). 
Perceptions of Crispi began to change in the British press after the establishment of the Kingdom of Italy. According to an article published in June 1862 Crispi and his parliamentary opposition were still problematic as 'hot-headed partisans of the Left', albeit no match for Rattazzi in parliamentary duels, but, at least, they now compared favourably with the 'single-minded, thoroughpaced, perhaps, dull-witted worthies of the Right' (The Times, 10 June 1862). By the mid-1860s, The Times was still portraying Crispi - not inaccurately - as fiery, but no longer did the paper label him a dangerous radical. Indeed, by the late 1860s, Times journalists began to attach more positive adjectives to his name - in one article he was 'the astute Crispi' - and the policies he advocated began to be assessed on their merits rather than simply on the basis of prejudice against his perceived republicanism and former revolutionary ardour. As the 1870s progressed Crispi came to feature with ever more regularity in articles on Italian politics but also increasingly, at least within the columns of the newspaper (for which Stillman became a regular correspondent in 1877 [Dyson, 2014, 247]), ${ }^{7}$ as a talented parliamentarian, a determined player in international affairs, and as a potential leader of a government, although on occasion he was clearly seen as intractable and possibly dangerous. ${ }^{8}$ As we shall see, Crispi continued to excite debate, and this had not diminished when Stillman made that first visit to him in the Consulta. But whatever Crispi's shortcomings and virtues, whether of character or politics, by the time he assumed office as prime minister, no one doubted his stature. This stature Stillman emphasised repeatedly not only in the articles that he wrote for The Times but in his longer works.

\section{Stillman's Crispi and Italian decadence}

Stillman's 1894 article for The Century Magazine runs to just six pages, rich in biographical detail and praise for Crispi. Despite its brevity, it is an important piece, not only because it laid down the essentials of Stillman's interpretation of his Italian hero, but also because it appears to have been a sketch of the biography, which was largely written on holiday in Switzerland during the summer of 1895 (Dyson, 2014, 269). The article's overwhelmingly positive assessment was, needless to say, more persuasive over a year before the disaster of Adowa in March 1896, a decisive defeat for Italy in Ethiopia, discredited Crispi's second ministry, and led to the prime minister's resignation. For Stillman himself the date was less important: he always refused to attribute any blame to Crispi for Italy's greatest humiliation since Lissa. ${ }^{9}$

Stillman's article was accompanied by an engraving of Crispi based on a photograph taken by Stillman himself. The inclusion of the portrait, an imposing profile, characterised by Crispi's heavy walrus moustache, is significant because the journalist made much of the statesman's physiognomy. Crispi's mien was often compared with that of Bismarck. In his article, Stillman used the physical similarities between the two to rebuff arguments that Crispi might be 'aping' the Prussian.

[...] a glance at the portrait of him which accompanies this article will show that Nature had provided the similitude before either knew of the other. The type of character is the same; the strongly marked jaw, the spacious brain, the eye that looks you through like a lance and yet is full of affectionate welcome at need, and the expression of inflexibility in pursuit, are common to both, as is also the high appreciation of authority and discipline; but beyond this there is little resemblance, and their political ideas differ entirely. (Stillman, 1894, 208) ${ }^{10}$

Stillman's article provided a lively narrative, which traced Crispi's education and sentimental 
knowledge of the island necessary for victory, and was the 'factotum' of the expedition; it was Crispi and not Garibaldi who was responsible for the victory at Monreale, proving more tactically astute than the great general; it was 'his three years' tenure of the premiership [that] was the most fruitful period in effective legislation during many years [...]'; and it was not Crispi who should be blamed for escalating governn expenditure on military expenses and desperate state finances, but Quintino Sella (1827-188 'the father of megalomania' - who had served three times as Minister of Finance in the 1860s. Crispi was, in Stillman's view never 'dictatorial' but was rather a model of sound government, respect for the crown, 'scrupulous [...] adherence to the letter of constitutional law', effective retrenchment and sensible management of the national finances, and intelligent foreign policy based not on his 'close friendship' with Bismarck but on building on the work of his predecessors. Any negative views of Crispi that ran counter to Stillman's hagiographic portrait, the journalist attributed to misrepresentation by the Sicilian's enemies, 'the trivial insolence of radicalism and the grave malignity of conservative hatred' (Stillman, 1894, 207-208). For Stillman, Crispi's 'self-reliance [was] phenomenal,' and his character and determination unique.

I do not believe that his devotion will save Italy from the civic decay and corruption into which she is sliding, but he will stand in history as a study of what Italian statesmanship might have been, and in fact has been, when the state is swept by the social revolution which its politicians are all playing with.

(Stillman, 1894, 208)

If what really set him Crispi apart from other Italian politicians was his character, what determined this was his ethnic origins. While Bismarck's character was dictated by the 'overweening masterliness of his Prussian stock', Crispi was in essence neither Sicilian nor Italian: while he was born in Ribera near Selinunte, and educated in Palermo,

[h]is family was one of those which migrated from Albania after the defeat by the Ottoman hordes of the hero of his race, the legendary Scanderberg, and went to land where [...] they could keep their Christian religion in tranquillity. [...] Four hundred years of Italian life have not in him affected the temper of his race, and Crispi possesses all the Skipetar traits - tenacity, courage, their curious reticence, and patriotic devotion, in this case only transferred to Italy. (Stillman, 1894, 203).

The 'fidelity and the individuality' that marked out Crispi from the decadent and, to Stillman's eyes, largely contemptible modern Italians was because Crispi was racially distinct. Running through Stillman's writing on Italy was the idea that Crispi - almost alone among modern Italians - offered hope. Like many anglophone 'friends' or 'lovers' of Italy in the post-unification period, the American polymath entertained an extremely low opinion of Italians - and especially of Italy's ruling elites - and in reality was neither friendly nor loving towards them. In his autobiography, for example, immediately after a passage that asserted that 'while generally credited with a good deal of meddling', he had only once ever sought to advise Crispi, Stillman viciously attacked the nature and conduct of Italian political life:

The conduct of the Italian factions and politicians during the two years of the second ministry of Crispi, the internecine war of intrigues to which the King lent a negative but effectual assent, and which ended in the disaster of Adowah, showed me that the Italian commonwealth is incurably infected with political caries, and that, though the state may endure, even as a constitutional monarchy, for years, the restoration of civic vitality to it is only to be hoped for under the condition of moral renovation, to which the Roman Catholic Church is an unsurmountable obstacle, because the Church itself has become infected with the disease of the state, - the passion of personal power, carried to the fever point of utter disregard of the general good. The liberty for which the extreme party in Italian politics agitates is only license, and, with the exception of a few amiable and impracticable enthusiasts in the extreme Left and a few honest and patriotic conservators of the larger liberties towards the Right, there are nothing but self-seekers and corrupt politicians in the state. During the years of my residence in Italy, 
the strengthening conviction of these facts has dampened my early enthusiasms for its political progress and my faith in its future, and, retiring at the limits of effective service from a position into which I had entered with sympathy, I buried all my illusions of a great future as I had those of a healthy Greek future. My profound conviction is that until a great moral reform shall break out and awaken the ruling classes, and especially the Church, to the recognition of the necessity of a vital, growing morality to the health of the state, there will be no new Italy. The idle dreamers who hope to cure the commonweal by revolution and the establishment of a republic will find, if their dream come true, that to a state demoralized in its great masses, more liberty can only mean quicker ruin. (Stillman, 1901, 711-12)

If Stillman lacked optimism about the future of Greece, he believed that at least

the Greeks are preserved from a moral decay like that which threatens Italy by the domestic morality due in part to temperament, but in part also to the influence of the clergy, who [...] are generally men of pure domestic morality and leaders of the common people. (Stillman, 1901, 713)

This contrasted starkly with Italy, where the key problem was the Catholic Church, a 'great human machine organized, disciplined like an army, for a war of shadows and formalities' and 'employed in the conquest of political influence' (Stillman 1901, 713). While protesting that he admired the pope, as 'an amiable, excellent ecclesiastic' (Stillman 1901, 714), and had no argument with Catholic teaching or dogma, had many Catholic friends, and would not 'join in the indiscriminate denunciation which is common among Protestants' (Stillman, 1901, 715), Stillman made it clear that

For the evil influence $[\ldots]$ which to-day has its seat at the Vatican [...] I have no respect, and only the feeling due to unmitigated evil. It is a deadly political malady, malefic in proportion to its influence on the people; and, I fear, until Italy is freed from it, no possible or healthy political life or morality is possible. (Stillman, 1901, 715)

For all his hostility to the Vatican, Stillman believed that 'The suppression of the Roman Catholic religion in Italy, if possible, would be only to leave its place vacant for unreason and anarchy, for the intellectual status of the common people does not admit of a more abstract belief' (Stillman, 1901, 715). Elsewhere in his autobiography, Stillman took aim at almost all elements of Italian society for the failings of the post-unification nation. Thus, for example, the disaster of Adowa had nothing to do with his adored Crispi, but was 'morally if not technically divided between Baratieri [the Italian commander] and certain parties in the court and army cliques more desirous of overthrowing Crispi than of securing a victory' (Stillman, 1901, 723); meanwhile, King Umberto was 'more than any other person, the cause of the decline and anarchy in parliamentary government in Italy' (Stillman, 1901, 724). It was, in his narrative, the growing conviction that 'Nothing less than the courage and abilities of a Cromwell could reform government in Italy, and, in the opinion of some of the wisest and most patriotic Italians I know the task is hopeless and the decay inevitable' that led Stillman to decide that he could no longer write on Italy for The Times, and led to his return to live in England (Stillman, 1901, 726).

In Francesco Crispi, Stillman displayed a similar level of admiration for the completely honourable and self-sacrificing statesman, who was always totally committed to Italy but never interested in personal gain or ambitious for his own glory, only for that of the nation. Summing up Crispi at the end of the volume, Stillman emphasised that, despite the scandals that had dogged his career, the Sicilian was simply 'incapable of using his official position for his pecuniary advantage' and 'refused advancement and competence under Cavour' rather than compromise his principles (Stillman, 1899, 222). In short, Crispi was the last remnant of a heroic era, the 'solitary survival of an epoch when there were giants in the land', in an Italy in which, forty years after the 
establishment of the new kingdom, 'only respectable and inoffensive mediocrity can be permitted to survive' (Stillman, 1899, 223). What was clear to Stillman was that while 'Amongst the masses at large he is the only man in politics who is capable of exciting any enthusiasm', Italian 'public opinion' in general, and the political elites in particular, had little stomach for Crispi's vision of 'a living and growing Italy [...] with ambitions for the assignment of a rôle amongst the powers, such as a nation with a population of thirty millions has a right to take'. If there were many in the population as a whole - these 'good and docile people' - who were happy to see Crispi exercise 'a strong authority able to correct abuses' (Stillman, 1899, 223), Crispi's yearning for great power status fell on deaf ears.

The result of the last ten years is to show, even him, that this was an idle dream. Italy is incapable of any foreign policy but that of a protected power. Civic virtue is at too low an ebb for the nation to have any active policy. The conflict of personal ambitions has eaten up the general well-being of its Government; corruption in its legislative and judicial regions, increasing rather than diminishing, has destroyed the confidence of the masses, which is the main strength of every good government. Crispi's dream was an idle one, and perhaps his greatest sorrow is to see his disillusion. (Stillman, 1899, 244)

Stillman's high regard for Crispi and disillusionment with the Italian nation also underpinned his Union of Italy (1898). But while in this account of recent Italian history the part played by Crispi in the process of unification was as exaggerated as elsewhere in Stillman's writings, his judgment on the new Italy was, if anything, even more vicious than in either autobiography or biography. Although the Union was the first to be published of Stillman's three books that deal with Crispi, its more general subject matter meant it was the one that endured longest on the shelves. A posthumous second edition was published in 1909, with an epilogue by the great Whig historian G.M. Trevelyan (Stillman, 1909, 394-398). In the Union, Stillman's final assessment of unification and its legacy is damning. 'The premature annexation of Naples, and the unfortunate necessity for the transfer of the capital of the capital to Rome, have introduced elements of discord into the kingdom that menace gravely, if not invincibly, the existing political system.' Rather than the 'enlarged Piedmont' modelled on England that had been desired by Cavour, the united Italy had become instead 'an enlarged Naples, without the vigorous, if treacherous, internal rule, and the consistent and uniform foreign policy of the Bourbons'. Stillman ended his book by quoting the maxim of contemporary Italian naysayers that 'Too quickly and too easily was Italy made' (Stillman 1898, 393).

When Trevelyan - fresh from publishing the first of his Garibaldi trilogy, and in the process of writing Garibaldi and the Thousand (Trevelyan 1907 and 1909) - added an epilogue to the second edition of The Union of Italy, he did his best to mitigate what Stillman himself had in his preface described as his 'somewhat pessimistic judgment' (Stillman, 1898, v), and which Trevelyan characterised as the author's 'note of extreme pessimism' (Stillman, 1909, 394). Trevelyan sought to be positive about the more democratic and constitutional outlook of the new king, about the Vatican's having 'accepted the fact of the Italian Kingdom', about the country's status as 'thoroughly constitutional [...] a nation bound together by a common feeling of patriotism embracing all classes', and about a rapid progress in 'both finance and commerce', including cooperative banks, hydroelectricity, and silk and cotton industries to rival those 'at Lyons and even in Lancashire'. Dismissive of the idea that 'any federative system could have been worked' (Stillman, 1909, 394-397), Trevelyan rejected Stillman's assessment that Italy had been united too swiftly and with too much facility:

If the golden moment of 1860 had not been seized, it may be that she would even now be one half dependent on France, and the other half divided between Austria, Pope and Bourbon. The present is not perfect, but there is much to be thankful for. (Stillman, 1909, 398).
388 
Despite his defence of the process and timing of the Risorgimento, in Trevelyan's commentary on Stillman and the legacy of unification, there is much that echoes the opinions of the late Times journalist: the social problems of the country remained 'acute', 'aggravated by the weight of a most unscientific system of taxation' (designed to pay in large part for 'armaments which are held, rightly or wrongly to be the condition of Italy's independence as a nation'), as well as 'by primitive methods of agriculture'; the Church was still 'opposed to all intellectual advance'; progress is 'confined too much to the north'; 'Sicily, even before the earthquake [of 1908] was in a terrible condition'; 'No one can deny the corruption and incompetence of too many branches and grades of the civil service'; 'No one can pretend that a great statesman has arisen in our day'; Giolitti, Trevelyan judges as no more than 'a very skilful manipulator of elections'; 'No doubt the south and to some extent Rome herself, have dragged down the standard of Italian politics and administration below what it would be if "Italy" only meant North Italy" (Stillman, 1909, 395-397). Trevelyan's view was not quite as dark as Stillman's, but it is hard not to get the sense that the optimism of Garibaldi's biographer was rather shallow.

\section{The British press and the failure of liberal Italy}

That even Trevelyan, seeking to attenuate Stillman's negative assessment of Italy's state in the years after unification, was forced to endorse so many of the late journalist's negative judgments is indicative of the low opinion in which liberal Italy was generally held. The initial enthusiasm for unification had soon evaporated, and, among British (and, indeed, American) commentators there was a widespread sense of disillusionment. Stillman had emphasised that his own pessimism did not reflect a negative attitude to Italians as a whole.

Nor does the author's pessimism extend to the character of the people of the peninsula in general, or affect his opinion of the many sterling qualities of the race, in which are included all those necessary for the realization of the ideals of its most sanguine patriots. (Stillman 1898, v)

But such protestations hid an essential exasperation about the failings of the Italian national character, which had increasingly become the norm in the anglophone world in the aftermath of unification. In one sense this simply echoed the sentiments of Italians themselves. The notion that the Italian nation needed regeneration - a radical change in morals and manners, a recovery of virtue, a renewal of education, a process of militarisation - was a longstanding one that could be traced back to Machiavelli and beyond (Patriarca 2005 and 2010). Any negative view Stillman entertained of Italian national shortcomings probably came in large part from the likes of Crispi himself - ever swift to inveigh against the shortcomings of his compatriots - and the sometime minister and historian Pasquale Villari. Stillman described Villari as 'one of the most devoted, honest and patriotic of living Italians and for years one of my best friends in Italy' (Stillman 1899, 703), but he was also the author of the savage indictment of the failings of Italian state and society that had resulted in the fiasco of 1866: 'Di chi è la colpa?' (Villari 1866 and 1868).

Negative views of contemporary Italy were regularly fed to the reading public in North America and the British Isles by Italian writers: as a long review article of works by American political scientist and future president of Harvard, Abbott Lawrence Lowell (1856-1 (Adcock 2017, 189-190), Pasquale Villari, and Villari's fellow Neapolitan Pasquale Turiello in the Edinburgh Review of 1897 pointed out, unfavourable views of the state of Italy were 'not the mere fancies of a splenetic traveller' but rather a product of Italian writing: 'The whole tone of social and political literature in Italy is desperately pessimistic' (Edinburgh Review, 3).

To British observers in the 1890 s, the question was not whether Italy needed radical change. Very few would have disagreed with the notion that dramatic reform was essential. Rather it 
focused on whether Crispi or someone like him was an appropriate means of effecting such reform. As can be seen from some of the hostile reviews of Stillman's work, by no means all commentators writing for British (or American) audiences agreed with the journalist's assessment either of Crispi or with his diagnosis of how to address the problems of modern Italy. Nevertheless, anglophone supporters of Crispi were by no means rare. Possibly the only one to be even more vociferous in d $\rightarrow$ ling the great Sicilian was another Europeanised American, William Livingstone Alden (18 1908). Like Stillman, Alden had been a US consul in Rome, and, again like Stillman, he sought to exculpate Crispi entirely from mistakes, especially those in Africa. In an article for the Contemporary Review of January 1897, Alden argued that Crispi had not only presciently warned of dangers in Italy's African policy, but 'was in no way responsible for Adowa' (Alden, 1897, 117-122). Two years earlier, Alden had written an article for The Nineteenth Century, the title of which made his position vis-à-vis Crispi absolutely clear: 'Francesco Crispi. An appreciation'. Here he argued that Crispi's greatness was 'due to the force and subtlety of his intellect, rather than to his [undoubted] courage and determination' (Alden, 1895, 165):

If keenness and broadness of intellect, knowledge of men and affairs, fearlessness and incorruptibility, patriotism that is passion, fidelity to friends that never wavers, and disdain for enemies so complete that vengeance offers no temptation - if these things make a great man, there have been few greater men than Francesco Crispi, the conspirator, the soldier, the statesman, the patriot, the last of the heroes who made Italy. (Alden, 1895, 176)

There were other writers who showed a similar readiness to endorse Crispi: G.M. James, writing for The Review of Reviews remarked in the regular 'Character Sketch' - a feature in William Thomas Stead's journal, which occasionally dealt not with an individual but with a rival publication, the events of a whole year, or, on one occasion, the entire Liberal Cabinet - that:

Crispi is a man born to rule, if any man is. Of inflexible character, and of uncompromising patriotism, his defects are those of strength, not, as is generally the case with Italian public men, of weakness and irresoluteness, if not of corruption. (James 1894, 537)

Plenty of commentators were not so ready to heap lavish praise upon Crispi, variously seeing him as a symptom of the shortcomings of liberal Italy, and even their principal cause. The popular Victorian novelist Maria Louise Ramé, who published under the pen name Ouida (1839-1908) and who had taken up permanent residence in Tuscany in the early 1870 s, became a scathing critic of iberal Italy's institutions and politics. In an article, which was in effect a review of Guglielmo Ferrero's La Reazione (Turin: Olivetti, 1895), the dog-obsessed, antisemitic, and prolific author of novels and children's stories, described the Italian statesman as 'something of the mattoide, of the monomaniac', a former 'regicide' who in his old age had become 'a liberticide':

Whoever has seen him speak when irritated, seen his inflamed countenance, his furious eyes, his gnashing teeth, has seen a man in whom the serene equilibrium of the brain is violently and frequently disturbed [...] Not only is passion his sole motive power, but in him the passions reach an incredible intensity with an incredible rapidity. (Ouida 1895, 241-242).

From Ouida's perspective it was clear that any prolongation of Crispi's influence would mean 'unlicensed persecution and prosecution' (Ouida 1895, 254). As she wrote in another article shortly after the battle of Adowa:

Much obloquy and misrepresentation has been incurred by those who have had the courage to resist the Crispi pressure, and divination clear enough to foresee the results of the Crispi policy. [...] In the pages of this Review I have repeatedly maintained those (in England) unpopular opinions, and I should not be human if I did not rejoice in the present proof of their accuracy, deeply as I lament the danger and wretchedness through which Italy has been dragged by the now fallen Minister. (Ouida, 1896, 541) 
Ouida was often attacked for her slapdash attitude to the Italian language, and her cavalier inaccuracies (significantly she called Guglielmo Ferrero 'Giovanni' in her review), but she was genuinely passionate in her opposition to the damage wrought on the lives of ordinary Italians by the misguided policies of the liberal state (Ambrosini 2013, 165), especially heavy taxation and conscription, which she rightly attributed to Italy's attempt to maintain overly large armed forces due to its aspiration to great power status. Rather than seeing Crispi as the means of addressing the shortcomings of united Italy, Ouida argued that he not only aggravated them but also frequently caused them. Similar, if more moderately expressed views were entertained by Mazzini's biographer Bolton King and his collaborator, Cambridge's first Serena Professor of Italian, the former basket-maker and autodidact Thomas Okey. They recognised Crispi as an able parliamentarian, but censured him for much else: for the 'great disaster of Adowa'; for his 'wild, unscrupulous ambitions [that] had brought the great humiliation'; for his recourse to 'coercion' that 'created a feeling of disgust and indignation'; for his 'barren imperialism' (designed to distract from his domestic policies), which 'singularly failed', 'soon lost its glamour', and generated 'wrath and panic' (King and Okey 1901, 6, 86-87, 307).

Amid the American and British voices for and against Crispi, Italians managed to have their say in the anglophone world. The British press remained happy to print translations from Italian (including the prose of Crispi himself [Crispi, 1898]), and articles commissioned from prominent Italian journalists, academics, and public figures. It is perhaps predictable, that Italian commentators often appeared both better-informed and more judicious in their assessments of Crispi. Sometimes, too, they could be quite severe in their analysis of British policy towards and perceptions of the peninsula. The Italian economist, radical, and future anti-Fascist Antonio de Viti de Marco, saw self-interest in British friendliness towards Crispi, explaining it in terms of the degree or equilibrium he brought to the Mediterranean and the relative stability he promised on the domestic front: 'It is easy, then, to understand the preference shown by the leading English papers for Signor Crispi, expansionist abroad, high-handed and despotic at home' (De Viti de Marco, 1895, 548).

Giuseppe Fiamingo, one of the founders of sociology as a discipline in Italy (Cipriani 2013), offered an assessment of Crispi, shortly after his death in August 1901, to the readers of Macmillan's Magazine. Fiamingo's judgement of Crispi emphasised that his character was 'not an Italian type' but distinctively Sicilian: the two-time prime minister had possessed an 'exaggerated sentiment of individuality [...] very common in Sicily': 'In the Sicilian what prevails is the worship of force which is suggested by his surroundings, by nature, by legend, by history itself' (Fiamingo 1901, 25-26). For Fiamingo, Crispi was totally devoted to the Italian cause and without question 'one of the greatest political figures of the past century'. And yet his legacy was far from positive: 'the only vestige of his work is the financial exhaustion brought about by his government' (Fiamingo, 1901, 29).

\section{Conclusion}

In August 1901, Stead's Review of Reviews devoted a second 'Character Sketch' to the recently deceased Crispi. The Italian author, Giovanni Dalla Vecchia, began the piece with the remark that:

The nature of Francesco Crispi was so complex that it would be equally possible to make an angel of him, as the late Mr. Stillman did, or a devil [...], but both presentations would be untrue. Crispi was neither the one nor the other. He had the bad and good qualities of a powerful man. His power no one ever denied, though at the same time many disagreed with the use he made of it. He had a very high conception of his own importance and power; many of his countrymen held him in a very high 
estimation, but one can safely say that he thought himself to be above the highest appraisement possible. [...] (Dalla Vecchia, 1901, 144)

Six years earlier, Guglielmo Ferrero, whose La Reazione had inspired Ouida's most savage attack on Crispi, had written:

The Crispi phenomenon will remain among the strangest and most curious aspects of Italian history this century; and his dictatorship will be one of the problems that will occupy historians in the future. Nobody has been able to impose his own personality on the entire country as he has, or stamp the political life of the nation so forcefully with his character, or arouse such enthusiasm, such hopes, such hatred. Nobody has so completely eclipsed the political world around him. (Ferrero cited in Duggan 2013, 21).

Fascination with Crispi led Stillman, the multi-talented, Europeanised American, to believe that the former Mazzinian and garibaldino was the one man who might save Italy. The Times journalist's realisation that the problems faced by Italy were not surmountable even by a man of Crispi's energy did not, alas, serve as an effective warning against the danger of the charismatic, dictatorial, and bellicose leader who would offer swift solutions for the peninsula's shortcomings. But Ferrero's prophesy has proved correct: Crispi's period of political dominance has continued 'to occupy historians', and continues to generate debate as the lively responses to Stillman's first English-language biography of Crispi and Christopher's great study of the great man have shown.

\section{Note on contributor}

David Laven is Associate Professor of History at the University of Nottingham. He is the author of Venice and Venetia under the Habsburgs, 1815-1835 (OUP, 2002), and numerous essays and articles on the British and Italy, nineteenth-century Venetia, the Italian Risorgimento, Italian identities, and the history of historiography. He has recently written the chapter on 1797-1866 for the Treccani illustrated history of the Veneto, and is currently completing a study of historians of the Venetian Republic 1815-1922.

\section{Notes}

1. Stillman's expertise in photography ran to producing an authoritative handbook on the subject. See William Stillman, The Amateur Photographic Guide Book, being a complete résumé of the most useful dry and wet collodion processes especially for the use of amateurs (London: C.D. Smith \& Co., 1874).

2. Georgi emphasises Stillman's diplomatic role in Rome from 1861 to 1865 , but wrongly suggests that Stillman was Crispi's advisor.

3. Stillman's fellow American, the Paris-based journalist and long-term correspondent for The New York Evening Post, Stoddard Dewey (1853-1933) wrote early in 1895 that "A campaign of "literature with a tendency" has been going on for some time in the English and American Press, in the interests of Prime Minister Crispi'. He identified as the two main culprits, Stillman and William Livingstone Alden (Dewey, 1895, 118).

4. Richard Davey, 'The Autobiography of a Journalist', The Speaker 13 July 1901, 422. The Speaker had recently added 'the liberal review' to its name and was under the editorship of the progressive John Lawrence Hammond. Peter Clark, Liberals and Social Democrats (Cambridge: Cambridge University Press, 1978, 81-82).

5. Notwithstanding the key part he played in events in Sicily during the mid-century insurrection, Crispi's mention in other newspapers in 1848-1849 are equally rare and laconic. For another mention of his name, but no more, see Daily News, 7 February 1848.

6. The opinions expressed in a handful of articles in September 1860 are reasonably typical: see the Dublinbased Freeman's Journal and Daily Commercial Advertiser, which spoke of 'the notorious Crispi, whose unpopularity in Sicily almost balances the enthusiasm for the Dictator who protects him'; The Morning Chronicle, which pointed to the fact that the pro-Cavour press had dubbed Crispi 'Garibaldi's evil genius'; and 'The Revolution in Southern Italy', The Daily News, 21 September, and The Standard, both of which pointed to Crispi as a bad influence on Garibaldi. 
7. Stillman had first written for The Times in 1875, but regular contributions started only in 1877 (Dyson 2014, 247).

8. See, for example, the article on Crispi's attitudes to Germany and the MacMahon government in France, The Times, 8 October 1877.

9. Duggan highlights that while there was much parliamentary opposition to Crispi, and massive public demonstrations against him in the aftermath of Adowa, the responses to the defeat, and, indeed, to his colonial policy in general varied greatly across Italy. (Duggan 2002, 708-709).

10. The nineteenth-century debate on physiognomy and phrenology had received an impulse from Italian writers such as Cesare Lombroso and Paolo Mantegazza. For coeval English responses to the latter today less well-known - see Bow Bells 1890. For the research of Paolo Mantegazza, see Saturday Review of Politics, 1890.

11. Stillman similarly emphasised Crispi's role in the success of Garibaldi's Thousand and the seizure of Sicily in The Union of Italy and Francesco Crispi. See 312-316 and 62-108 respectively.

\section{References}

Adcock, R. 2017. Liberalism and the Emergence of American Political Science. A Transatlantic Tale. Oxford: Oxford University Press.

Alden, W.L. 1895. "Francesco Crispi. An Appreciation." The Nineteenth Century: A Monthly Review 37 (215), January: 165-176.

Alden, W.L. 1897. "Erythrea.” The Con orary Review 71, January: 117-122.

Ambrosini, R. 2016. "Politicizing the Ae ic: Ouida's Transnational Critique of Modernity." In Ouida and Victorian Popular Culture, edited by J. Jordan, and A. King, 165-182. Abingdon: Routledge.

Cipriani, R. 2013. "The Italian sociological tradition." Sociologia Italiana 2:143-159.

Crispi, F. 1898. "The antidote for anarchy. Difficulties that confront the nations. Forecast of the conference results." The Daily Mail 807, 30 November: 4.

Dalla Vecchia, G. 1901. "Character Sketch: Francesco Crispi." Review of Reviews, August 144-150.

de Viti de Marco, A. 1895. "The political situation in Italy." The Nineteenth Century. A Monthly Review 38 (224), October: 548-560.

Dewey, S. 1895. "Fran Crispi." The Speaker: the liberal review 11, 16 February: 118-120.

Duggan, C. 2000. Cred nazione. La vita di Francesco Crispi. Rome-Bari: Laterza.

Duggan, C. 2002. Francesco Crispi, 1818-1901: From Nation to Nationalism. Oxford: Oxford University Press.

Duggan, C. 2013. "Political cults in liberal Italy, 1861-1922." In The Cult of the Duce. Mussolini and the Italians, edited by S. Gundle, C. Duggan, and G. Pieri, 11-26. Manchester: Manchester University Press.

Dyson, S.L. 2014. The Last Amateur. The Life of William J. Stillman. Albany, New York: State University of New York Press.

Ehrenkranz, A., C. Ficler, L.S. Ferber, and A. James. nd [1988]. Poetic Localities. Photographs of Adirondeack Calbello, Crete, Italy, Athens. New York: Aperture.

Ferrero, 128 5. La Reazione. Turin: Olivetti.

Fiamingo, G.M. 1901. "Francesco Crispi." Macmillan's Magazine 85 (505), November: 24-29.

Georgi, K.L. 2013. Critical Shift. Rereading Jarves, Cook, Stillman, and the Narratives of NineteenthCentury American Art. Pennsylvania: Penn State Press.

Gooch, J. 1998. "Italy, Abyssinia and the Sudan, 1885-98." In Sudan. The Reconquest Reappraised, edited by E. M. Spiers, 128-145. London: Frank Cass.

James, G.M. 1894. "Character Sketch. Francesco Crispi.” The Review of Reviews, December: 537-543.

John, A. 1981. The Best Years of the Century: Richard Watson Gilder, Scribner's Monthly, and The Century Magazine, 1870-1909. Urbana: University of Illinois Press.

King, B., and T. Okey 1901. Italy to-day. London: Nisbet \& Co.

Morren, D.G. 1967. "Donald Mackenzie Wallace and British Slavophilism, 1870-1919." Canadian Slavonic Papers 9 (2): 170-183. 
Ouida, 1895. "The Crispi Dictatorship." The Contemporary Review 68, August 241-255. 659

Ouida, 1896. "The Italian Awakening." Fortnightly Review 59 (352), April: 541-546. 660

Patriarca, S. 2005. "Indolence and Regeneration: Tropes and Tensions of Risorgimento Patriotism." 661 The American Historical Review 110 (2): 380-408. 662

Patriarca, S. 2010. Italian Vices. Nation and Character from the Risorgimento to the Republic. Cambridge: 663 Cambridge University Press.

Smith, H.F. 1970. Richard Watson Gilder. New York: Twayne Publishers.

Stillman, W.J. 1874. The Cretan Insurrection of 1866-7-8. New York: Henry Holt.

Stillman, W.J. 1891. "The Crisis at Rome', dated 1 February.” The Times 33241, 6 February: 13.

Stillman, W.J. 1891. “The New Italian Ministry', dated Rome 10 February.” The Times 33249, 16 February: 4.

Stillman, W.J. 1894. "Francesco Crispi." The Century Magazine 31:203-209.

Stillman, W.J. 1897. "The Old Rome and the New." In W.J. Stillman. The Old Rome and the New and Other Studies, 1-24. London: Grant Richards.

Stillman, W.J. 1898. The Union of Italy. 1815-1895. Cambridge: Cambridge University Press.

Stillman, W.J. 1899. Francesco Crispi. Insurgent, Exile, Revolutionist, and Statesman. London. Grant Richards.

Stillman, W.J. 1901. The Autobiography of a Journalist 2 vols. London: Grant Richards; Cambridge, Mass.: Riverside; Boston: Houghton, Mifflin, \& Co.

Stillman, W.J. 1909. The Union ly ly. 1815-1895. 2nd edition. Cambridge: Cambridge University Press.

Sutherland, J. 1989. The Stanford Epanion to Victorian Fiction. Stanford, California: Stanford University Press.

Trevelyan, G.M. 1907. Garibaldi's Defence of the Roman Republic. London: Longmans, Green \& Co.

Trevelyan, G.M. 1909. Garibaldi and the Thousand. London: Longman, Green \& Co.

Villari, P. 1866. "Di chi è la colpa? O sia la pace e la guerra." Il Politecnico parte letteraria, series IV, 2 (3), September: 257-288.

Villari, P. 1868. "Di chi è la colpa? O sia la pace e la guerra." In P. Villari, Saggi di storia, di critica e di politica, 385-422. Florence: Tipografia Cavour.

\section{Articles in newspapers and periodicals listed alphabetically by title of publication}

'A Bismarck of the South', The Academy, 1423, 12 August 1899: 154-155.

'Crispi', The Bookman, 16/94, July 1899: 106-107.

'Physiognomy', Bow Bells: A Magazine of General Literature and Art for Family Reading, 10/122, 2 May 1890: 418.

'Revolution of Naples and Sicily', Daily News, 529, 7 February 1848: 2.

'Garibaldi's evil genius' and 'The Revolution in Southern Italy', The Daily News, 4481, 21 September 1860.

'Art. 1', The Edinburgh Review, 186/381, July 1897: 1-32.

'Sardinia and Rome', Freeman's Journal and Daily Commercial Advertiser, 11 September 1860.

'Garibaldi and the Sicilies', The Morning Chronicle, 29232, 18 September 1860.

'Reviews', The Observer, 9 July 1899: 7.

'A psychological senator', Saturday Review of Politics, Literature, Science, and Art, 69/1794, 15 March 1890: 307-308.

The Standard, 11268, 22 September 1860: 4.

'Naples and Sicily', The Times, 19779, 7 February 1848: 3. 


\section{Italian summary}

Nello scrivere la sostanziosa ric 2 grafia di Francesco Crispi, Christopher Duggan fa largo uso della corrispondenza del giornalista americano del Times, William James Stillman. L'articolo è incentrato su quanto Stillman ha scritto sull'uomo di governo italiano, specie nella sua storia di Italia dal 1815 edita nel 1898, in quella che è stata la prima ed unica biografia di Crispi in inglese prima di quella di Duggan, e nella stessa autobiografia del giornalista. Nell'articolo si sostiene che, nonostante il decantato amore di Stillman per l'Italia, questi fondamentalmente disprezzava la maggior parte degli italiani e interpretava le virtù di Crispi come un rifiuto della tipica condotta italiana. Mentre l'estremismo di Stillman nel sostenere Crispi non era affatto inusuale tra i commentatori inglesi e americani, la sua denigrazione degli italiani risultò sorprendentemente diffusa tra gli osservatori vittoriani della nuova nazione. 